\title{
PENERAPAN DIAGNOSA KEPERAWATAN DI BERBAGAI INSTANSI KESEHATAN
}

\author{
Audina Tio Junianti Manik \\ audina.junianti@gmail.com
}

\section{Latar Belakang}

Diagnosa keperawatan merupakan salah satu hal yang penting dari proses keperawatan. Diagnose keperawatan biasanya dilakukan setelah tahap pengkajian dilakukan. Diagnose keperawatan akan terlaksanakan dengan baik jika tahap pengkajian dilakukan dengan benar. Informasi yang didapat di diagnose keperawatan melalui pengkajian tersebut dipergunakan untuk menentukan asuhan keperawatan apa saja yang akan dipilih yang sesuai dengan terapi keperawatan.

Gordon (1976) dalam Capenito (2000) berpendapat bahwa definisi diagnosis keperawatan adalah suatu pernyataan yang menjelaskan respon manusia (status kesehatan atau risiko perubahan pola) dari individu atau kelompok, dan perawat secara akuntabilitas dapat mengidentifikasi serta memberikan intervensi secara pasti untuk menjaga status kesehatan; diagnosis keperawatan adalah masalah kesehatan aktual dan potensial. Berdasarkan pendidikan dan pengalamannya, perawat mampu serta mempunyai kewenangan untuk memberikan tindakan keperawatan berdasarkan standar praktik keperawatan dan etik keperawatan yang berlaku di Indonesia.

Dalam menyusun diagnosis keperawatan, diperlukan pengetahuan dan keterampilan yang dimiliki seorang perawat, seperti kemampuan dalam memahami beberapa masalah keperawatan, faktor yang menyebabkan masalah, batasan karakteristik, beberapa ukuran normal dari masalah tersebut, serta kemampuan dalam memahami mekanisme penanganan masalah, berpikir kritis, dan membuat kesimpulan dari masalah (Wadigdo, 2016). Dalam pernyataan diagnosis keperawatan, ada 3 komponen, yaitu $\mathbf{P}$ (Problem atau masalah), E (Etiologi atau faktor penyebab), dan $\mathbf{S}$ (Simptom atau dikenal dengan batasan karakteristik atau gejala).

Kriteria dari standar diagnosa keperawatan menurut Depkes RI (1998) yaitu diagnosa keperawatan dihubungkan dengan penyebab kesenjangan dan pemenuhan kebutuhan pasien, diagnosa dibuat sesuai dengan wewenang perawat, komponen terdiri dari masalah, 
penyebab, gejala $(\mathrm{P}, \mathrm{E}, \mathrm{S})$ atau masalah atau penyebab $(\mathrm{P}, \mathrm{E})$.

\section{Metode}

a) Didalam penulisan ini, saya menggunakan metode menganalisis dengan cara mengumpulkan beberapa jurnal e-book dari internet, membacanya, dan juga mengkompilasi isi dari berbagai jurnal serta $e$-book tersebut.

b) Dengan membandingkan metode-metode yang digunakan dari beberapa jurnal.

Disini saya hanya mengambil tiga jurnal saja untuk membandingkan hasil.

- Yang pertama adalah jurnal dari "PENGEMBANGAN INSTRUMEN PENEGAKAN DIAGNOSIS KEPERAWATAN PADA PASIEN CONGESTIVE HEART FAILURE (CHF)

BERBASIS STANDAR DIAGNOSIS KEPERAWATAN INDONESIA (SDKI)" oleh

Cikwanto dan Nupiyanti, yang menggunakan dua tahapan, yaitu

Tahap pertama adalah mengembangkan instrumen penegakan diagnosis keperawatan yang di dukung dengan analisis stastik menggunakan pearson product moment correlation test untuk menentukan validitas dan uji alpha cronbach untuk menentukan reabilitas. Pada tahap kedua adalah proses sosialisasi dan pelatihan dalam menggunakan instrumen sehingga perawat dapat menggunakan instrumen penegakan diagnosis keperawatan menurut SDKI.

- Yang kedua adalah jurnal dari yang berjudul "DIAGNOSIS KEPERAWATAN PADA PASIEN DENGAN GANGGUAN PENCERNAAN"oleh Putri Wulansari dan Heni Apriyani, yang menggunakan metode penelitian yang dilakukan di Ruang Penyakit Dalam RSD HM Ryacudu Kotabumi Lampung Utara. Waktu penelitian dilaksanakan selama 2 minggu (Juni - Juli 2015). Pengambilan sampel pada penelitian ini menggunakan teknik accidental sampling dengan kriteria sampel yaitu sedang dirawat di Ruang Penyakit Dalam dan bersedia menjadi responden. Alat yang digunakan dalam penelitian ini 
yaitu kuesioner yang disusun berdasarkan pengkajian NANDA -ISDA.

- Yang ketiga adalah jurnal yang berjudul "IDENTIFIKASI DIAGNOSIS KEPERAWATAN PADA PASIEN DI RUANG PARU SEBUAH RUMAH SAKIT" oleh Heni Apriyani, yang menggunakan metode penelitian deskritif yaitu penelitian yang bertujuan untuk mendeskripsikan (memaparkan) peristiwa penting yang terjadi pada masa kini (Nursalam, 2011). Dalam penelitian ini terdapat satu variabel yaitu diagnosis keperawatan pada pasien yang dirawat diruang paru RSD H.M. Mayjend Ryacudu Kotabumi Lampung Utara Tahun 2014.

\section{Hasil}

- Jurnal pertama yang berjudul "PENGEMBANGAN INSTRUMEN PENEGAKAN DIAGNOSIS KEPERAWATAN PADA PASIEN CONGESTIVE HEART FAILURE (CHF) BERBASIS STANDAR DIAGNOSIS KEPERAWATAN INDONESIA (SDKI)" oleh Cikwanto dan Nupiyanti, mendapatkan hasil bahwa diagnose keperawatan digunakan di ruang rawat inap RSUD Dr. H. Abdul Moeloek Provinsi Lampung dengan disesuaikan SDKI. Pada kolom 1 berisi komponen waktu yang terdiri terdiri Tanggal dan Jam yang diisi saat diagnosis tersebut ditemukan pada pasien. Untuk diagnosis keperawatan Aktual pada kolom 2 terdiri dari komponen diagnosis keperawatan yang terdiri dari

1) kode diagnosis keperawatan SDKI, komponen label diagnosis (problem) yang disertai dengan definisi masingmasing diagnosis,

2) komponen penyebab (etiology) berupa check list yang diisi sesuai dengan faktor penyebab pada masing-masing pasien,

3) komponen tanda \& gejala (symptom) Mayor pada sebelah kiri kolom berupa check list yang harus diisi lebih dari $80 \%$ tanda \& gejala, dan

4) komponen tanda \& gejala (symptom) Minor pada sebelah kanan kolom berupa check list yang jika ditemukan tanda \& gejala tersebut.

Pada kolom 5 perawat wajib memberi tanda tangan dan nama perawat yang mengisi instrumen tersebut. Untuk diagnosis keperawatan Risiko pada kolom 2 terdiri dari komponen diagnosis 
keperawatan yang terdiri dari 1) kode diagnosis keperawatan SDKI,

2) komponen label diagnosis (problem)

yang disertai dengan definisi

masingmasing diagnosis,

3) komponen penyebab (etiology) berupa

check list yang diisi sesuai dengan faktor penyebab pada masing-masing pasien.

Pada kolom 5 perawat wajib memberi tanda tangan dan nama perawat yang mengisi instrumen tersebut. Untuk diagnosis keperawatan Promkes pada kolom 2 terdiri dari komponen diagnosis keperawatan yang terdiri dari

1) kode diagnosis keperawatan SDKI, 2) komponen label diagnosis (problem) yang disertai dengan definisi masingmasing diagnosis,

3) komponen tanda \& gejala (symptom) Mayor pada sebelah kiri kolom berupa check list yang harus diisi lebih dari $80 \%$ tanda \& gejala, dan

4) komponen tanda \& gejala (symptom) Minor pada sebelah kanan kolom berupa check list yang jika ditemukan tanda $\&$ gejala tersebut. Pada kolom 5 perawat wajib memberi tanda tangan da

- Jurnal kedua yang berjudul

"DIAGNOSIS KEPERAWATAN PADA PASIEN DENGAN GANGGUAN PENCERNAAN"oleh Putri Wulansari dan Heni Apriyani,, mendapatkan hasil bahwa hampir separuh penyakit yang dialami pasien di Ruang Paru adalah Dispepsia, sebanyak 12 orang pasien, dan hanya 1 orang pasien dengan diagnose medik Thypoid, sebagian besar responden adalah laki-laki dengan rentang usia 4655 tahun. Dan hasil (berfokus pada pasien Dispepsia) diagnosis keperawatan aktual bahwa semua responden mengalami Nausea (100\%), dan hampir seluruhnya $(91,7 \%)$ mengalami nyeri akut. Sedangkan diagnosis keperawatan yang dialami responden dengan prosentase $50 \%$ aau lebih adalah gangguan pola tidur, gangguan menelan dan kerusakan membrane: mukosa oral. Diagnosis keperawatan risiko bahwa diagnosis keperawatan risiko jatuh, dan risiko ketidakseimbangan elektrolit dialami oleh lebih dari 90\% responden, sedangkan risiko respon allergi hanya dialami oleh 16,7\% responden. Potensial Komplikasi Pada Klien Dispepsia dari 12 responden Dispepsia, terdapat 5 reponden yang mengalami PC: hypernatremia, dan 5 responden mengalami PC:

Antihypertensive therapi adverse effects.

Diagnosis keperawatan Promosi

Kesehatan pada Pasien Dispepsia yang 
paling banyak terjadi adalah kesiapan meningkatkan pengetahuan (70\%).

- Jurnal yang ketiga yang berjudul berjudul "IDENTIFIKASI DIAGNOSIS KEPERAWATAN PADA PASIEN DI RUANG PARU SEBUAH RUMAH SAKIT" oleh Heni Apriyani mendapatkan hasil bahwa hampir separuh penyakit yang dialami pasien di Ruang Paru adalah TB Paru (36,7\%). Prosentase selanjutnya adalah Asma Bronkial (23\%), Pneumonia (20\%) dan Efusi Pleura (17\%), dan sebagian besar responden adalah berjenis kelamin laki-laki dengan rentan umur 51-60 tahun. Dari jumlah sampel 30 pasien, diagnosis yang ditegakkan pada pasien yang dirawat di Ruang Paru, berdasarkan pengkajian dengan menggunakan NANDA terdapat 17 diagnosis dapat ditegakkan, sedangkan diagnosis yang ditegakkan perawat sejumlah 4 diagnosis. Jika dilihat dari jenis diagnosis, diagnosis berdasarkan NANDA meliputi diagnosis aktual (actual diagnosis): 11 diagnosis, risiko (Risk diagnosis): 4 diagnosis, promkes (Wellness diagnosis): 1 diagnosis dan potensial komplikasi (Potensial complication): 1 diagnosis, sedangkan diagnosis yang ditegakkan oleh perawat seluruhnya adalah diagnosis aktual.
Diagnosis keperawatan yang paling sering muncul berdasarkan NANDAISDA adalah adalah Bersihan jalan napas tidak efektif (100\%), Pola napas tidak efektif (100\%), Risiko trauma vascular (100\%), Risiko jatuh (97\%), Defisit perawatan diri: mandi (93\%), Defisit perawatan diri: berpakaian (93\%), Defisit perawatan diri: eliminasi (93\%), Defisit perawatan diri: makan (93\%), Kesiapan peningkatan pengetahuan (90\%), Mual (77\%), Gangguan body image (70\%), PC: reaksi allergi (33\%), Ansietas (30\%), Ketidakefektifan performa peran (23\%), ketidakseimbangan nutrisi: kurang dari kebutuhan (20\%), Risiko trauma (13\%), dan Risiko distress spiritual (6\%). Daftar diagnosis di atas memperlihatkan hanya ada 2 (dua) diagnosis yang sama ditegakkan baik oleh perawat maupun diagnosis yang ditegakkan berdasarkan NANDA-ISDA, yaitu: Bersihan jalan napas tidak efektif dan pola napas tidak efektif. 


\section{Pembahasan}

Dari hasil-hasil yang telah didapat dari beberapa jurnal tersebut, dapat kita lihat bahwa ketiga jurnal tersebut menggunakan diagnosis keperawatan berdasarkan Standar Diagnosis Keperawatan Indonesia (SDKI) dan NANDAISDA.

Pada jurnal pertama, membahas karakteristik responden dilihat dari segi usia, jenis kelamin, lama bekerja, pendidikan terakhir dan status kepegawaian perawat yang mana didapatkan hasil bahwa. Tabel di atas dapat menginformasikan bahwa hampir sebagian responden $(61,5 \%)$ berusia 36-40 tahun, sebagian besar responden (92,3\%) adalah perempuan, hampir sebagian responden $(65,4 \%)$ lama kerja >16-20 tahun, sebagian besar pendidikan terakhir adalah D3 Keperawatan, dan seluruh responden (100\%) adalah pegawai tetap. Hal tersebut menunjukkan bahwa respondenmasih termasuk dalam kategori usia produktif dengan pengalaman kerja cukup lama. Secara keseluruhan, peserta dapat menerima materi yang disampaikan oleh peneliti, namun yang menjadi kendala adalah kurangnya informasi tentang textbook SDKI. Instrumen yang dikembangkan adalah untuk pasien dengan diagnosa medis chronic heart failure, sehingga perawat ditugaskan untuk menegakan diagnosis keperawatan pada pasien chronic heart failure.
Satu perawat bertugas menpenegakan diagnosiskan satu pasien chronic heart failure yang mana penegakan diagnosis tersebut diselesaikan dalam satu shift. Peneliti ikut mendampingi para perawat selama proses penegakan diagnosis keperawatan pada masingmasing responden yang penegakan diagnosis keperawatan pasien cronic heart failure sebagai pembanding apakah yang dipenegakan diagnosis oleh perawat sudah benar atau belum ${ }^{4}$.

Pada jurnal kedua, membahas mengenai

- Diagnosis Keperawatan Aktual: Nausea Munculnya diagnosis keperawatan Nausea, diperkuat oleh batasan karakteristik yaitu sensasi muntah, peningkatan saliva, melaporkan mual, dan peningkatan menelan (NANDA, 2012). Hasil wawancara kepada perawat, menyebutkan bahwa mual merupakan keluhan yang paling banyak dirasakan pasien dengan gangguan pencernaan.

- Diagnosis Keperawatan Risiko Risiko jatuh, merupakan diagnosis keperawatan yang paling sering muncul pada pasien dengan diagnose medik Dispepsia, Gastroenteritis, dan Gastritis. Hal ini sesuai dengan batasan karakteristik untuk risiko jatuh, yaitu 
mengantuk, sakit akut, diare, dan gangguan keseimbangan (NANDA, 2012).

- Potensial Komplikasi

Sangat jarang sekali perawat merumuskan diagnosis keperawatan yang bersifat kolaboratif atau disebut juga dengan potensial komplikasi. Masalah potensial komplikasi ditemukan pada pasien dengan gangguan pencernaan. Hal ini sesuai dengan Carpernito (2006) dalam Nurjanah (2012), bahwa proses pengkajian dapat menghasilkan tiga kesimpulan:

a. Memunculkan diagnosis potensial komplikasi (masalah kolaboratif)

b. Memunculkan diagnosis keperawatan

c. Memunculkan baik diagnosis keperawatan dan diagnosis potensial komplikasi .

- Diagnosis Keperawatan Promosi Kesehatan

Diagnosis keperawatan promkes bersifat sejahtera, ditandai dengan sesuatu yang menyenangkan pada tingkat kesejahteraan yang lebih tinggi dan ada status dan fungsi yang efektif (NANDA, 2012). Pada pasien dengan gangguan pencernaan, ditemukan diagnose keperawatan promosi kesehatan yaitu kesiapan meningkatkan pengetahuan dan kesiapan meningkatkan tidur. $^{11}$

Pada jurnal ketiga, membahas frekuensi kemunculan yang sering pada kedua diagnosis keperawatan ini (bersihan jalan napas tidak efektif dan pola napas tidak efektif.), tidak hanya dilakukan oleh perawat ruangan, namun juga berdasarkan pengkajian NANDA-ISDA. Hal ini sesuai dengan hasil penelitian (Andrade, et.al. 2012), bahwa diagnosis Pola napas tidak efektif, Bersihan jalan napas tidak efektif dan Gangguan pertukaran gas merupakan diagnosis keperawatan yang paling banyak ditegakkan oleh perawat berdasarkan serangkaian data pada pasien dengan gangguan pernapasan Pneumonia dan Asma. Diagnosis keperawatan yang ditegakkan berdasarkan pengkajian NANDAISDA lebih beragam daripada diagnosis keperawatan yang ditegakkan oleh perawat. Dengan NANDA-ISDA pengkajian dilakukan dari berbagai Aspek dan didasari pada pemahaman terhadap definisi suatu diagnosis tersebut (Nurjannah, 2010). Semua responden terpasang infus, namun tidak ada perawat yang menegakkan diagnosis keperawatan "Risiko trauma vaskular". Berdasarkan pengkajian NANDA-ISDA, data pemasangan infus akan memunculkan diagnosis keperawatan Risiko trauma vaskular. Menurut Saputra (2013), komplikasi pemasangan infus diantaranya adalah hematoma, infiltrasi, tromboplebitis dan emboli 
udara. Tidak satupun perawat menegakkan diagnosis keperawatan "Defisit perawatan diri : mandi, berpakaian, eliminasi dan makan”. Berdasarkan pengumpulan data diperoleh bahwa 28 responden mengalami defisit perawatan diri, dan berdasarkan pengkajian NANDA-ISDA responden mengalami defisit perawatan diri pada 4 aspek yaitu mandi, berpakaian, eliminasi, dan makan.Hal ini sesuai pendapat Brunner \& Suddarth (2002), bahwa kelemahan pasien yang dirawat di RS akan menyebabkan pasien memerlukan bantuan untuk melaksanakan aktivitasnya sehari-hari ${ }^{1}$.

Berdasarkan pengkajian NANDA-ISDA, tidak hanya diagnosis keperawatan yang bersifat fisik yang dapat ditegakkan, namun muncul pula masalah psikososial, misalnya Ansietas dan Ketidakefektifan performa peran ${ }^{1}$.

Dalam diagnosis NANDA-ISDA, ada 4 diagnosis yang ditegakkan dalam diagnose keperawatan, yaitu diagnosis actual, diagnosis resiko, potensi komplikasi, dan promosi kesehatan. Sedangkan SDKI dengan pilihan check list sesuai standar penyusunan diagnosis keperawatan yaitu terdiri dari problem, etiology, symptom untuk diagnosis aktual serta proble dan etiology untuk diagnosis risiko dengan format check list.

Para peneliti mengembangkan diagnosa keperawatan dan intervensi instrumen berdasarkan SDKI berdasarkan hasil FGD dan berdasarkan teori yang dijelaskan dalam paragraf sebelumnya. Instrumen telah dirancang oleh para peneliti disajikan dan ditawarkan kepada peserta. Sesuai dengan harapan para perawat yang ingin diagnosis mereka dan keperawatan instrumen intervensi yang sederhana ${ }^{4}$.

\section{Penutup}

Di dalam menentukan diagnosis keperawatan, bisa menggunakan enam langkah standar ISDA berdasarkan diagnosis ISDA dan NANDA, dan juga referensi lain seperti

Standar Diagnosa Keperawatan Indonesia (SDKI). Menggabungkan ISDA, NANDA dan SDKI untuk diagnosis keperawatan dapat membantu perawat dalam mengumpulkan data yang valid dan penentuan yang tepat dalam mendiagnosis. Dan tidak lupa juga menggunakan pengkajian yang tepat, karena pengkajian informasi yang benar akan menentukan diagnose yang benar pula. 


\section{Daftar Pustaka}

Apriyani, H. (2015). IDENTIFIKASI

DIAGNOSIS KEPERAWATAN PADA

PASIEN DI RUANG PARU SEBUAH RUMAH

SAKIT. Jurnal Keperawatan, XI(1), 107-111

Astar, F., Tamsah, H., Kadir, I. (2018).

PENGARUH PELAYANAN ASUHAN

KEPERAWATAN TERHADAP KEPUASAN

PASIEN DI PUSKESMAS TAKALALA

KABUPATEN SOPPENG. Journal of

Management, 1(2), 33-57.

Budiono.(2016).Modul Bahan Ajar Cetak

Keperawatan 'Konsep Dasar

Keperawatan'.Jakarta: Pusdik SDM Kesehatan

Badan Pengembangan dan Pemberdayaan

Sumber Daya Manusia Kesehatan

Cikwanto, Nupiyanti. (2018). Pengembangan

Instrumen Penegakan Diagnosis Keperawatan

pada Pasien Congestive Heart Failure (CHF)

Berbasis Standar Diagnosis Keperawatan

Indonesia (SDKI). JURNAL KEPERAWATAN

'AISYIYAH (JKA), 5(1),51-63.

Nurjannah, I., Pamungkas D.R., Warsini, S.

(2017). PERBANDINGAN ANTARA

DIAGNOSIS YANG SERING DITEGAKKAN

DAN POSSIBLE DIAGNOSIS YANG

DIPREDIKSIKAN OLEH PERAWAT PADA

KLIEN DENGAN GANGGUAN JIWA. Jurnal

Keperawatan Klinis dan Komunitas, 1(1), 8-15.

Rofi, M., Warsito, B. E., Santoso A., Ulliya, S. (2018). Diagnosa Keperawatan Yang Sering Ditegakkan Perawat Pada Pasien Tuberkulosis Paru Di Rumah Sakit. Jurnal Kepemimpinan dan Manajemen Keperawatan, 1(2), 1-8.

Simamora, R. (2009). Dokumentasi Proses Keperawatan.
Simamora, R. H., Purba, J. M., Bukit, E. K., \& Nurbaiti, N. (2019). Penguatan Peran Perawat Dalam Pelaksanaan Asuhan Keperawatan Melalui Pelatihan Layanan Prima. JPPM (Jurnal Pengabdian Dan Pemberdayaan

Masyarakat), 3(1), 25-31.

Widagdo, W., Kholifah, S. T. (2016). Modul Bahan Ajar Cetak Keperawatan 'Keperawatan Keluarga dan Komunitas'.Jakarta: Pusdik SDM Kesehatan Badan Pengembangan dan Pemberdayaan Sumber Daya Manusia Kesehatan

Wirdah, H.,Yusuf, M.(2016). PENERAPAN ASUHAN KEPERAWATAN OLEH PERAWAT PELAKSANA DI RUMAH SAKIT BANDA ACEH. JURNAL ILMIAH MAHASISWA FAKULTAS KEPERAWATAN,1(1).

Wulansari, P., Apriyani, H. (2016). DIAGNOSIS KEPERAWATAN PADA PASIEN DENGAN GANGGUAN PENCERNAAN. Jurnal

Keperawatan, XII(1), 40-45.

Wulandini, P., Krianto, T., Priwahyuni, Y. (2016). FAKTOR-FAKTOR YANG BERHUBUNGAN DENGAN PENDOKUMENTASIAN ASUHAN KEPERAWATAN DI RUMAH SAKIT JIWA. Ners Jurnal Keperawatan, 12(2), 131-142. 
